\title{
A PERSONAL PERSPECTIVE ON \\ LEGISLATION: NORTHERN MILK \\ REVISITED - SOURED OR STILL \\ FRESH?
}

Hon Douglas White QC*

The thesis of this article is that the overarching objective of statutory interpretation is to "make the Act work" as the Court of Appeal held in Northern Milk. This requires a common sense and practical approach. The article demonstrates the thesis by reference to subsequent Court of Appeal decisions and the complementary legislation establishing the Law Commission and the Parliamentary Counsel Office. The issues raised by the Law Commission's recently reactivated reference on the law of contempt of court are considered by way of example. The conclusion is that the Northern Milk approach remains apposite.

\section{INTRODUCTION}

This article is based on an address given to a forum of parliamentary counsel in June 2016 on my perspective on legislation.

My perspective on legislation is informed by my experiences in reading, interpreting and applying legislation over a lifetime in the law: as a student, as a practitioner, as counsel, as a judge, and now as a Law Commissioner. I was also privileged to be retained by the New Zealand Law Society to advise on the drafting of the Bill which became the Lawyers and Conveyancers Act 2006.

\section{PRELIMINARY THOUGHTS}

My first thought is somewhat trite and elementary, but nonetheless worth recording at the outset. It is difficult to overstate the importance of legislation to our democratic society. Statutes enacted by Parliament govern practically every aspect of our lives: from those establishing our constitutional

* President of the New Zealand Law Commission. This article has benefitted from discussion at a forum of parliamentary counsel in June 2016 as well as consideration of further relevant materials provided by Ross Carter of the Parliamentary Counsel Office and research by Jacob Meagher of the Law Commission. 
democracy, ${ }^{1}$ our fundamental rights, ${ }^{2}$ obligations ${ }^{3}$ and protections, ${ }^{4}$ through those enabling us to pursue our professional and occupational lives ${ }^{5}$ and our commercial and other aspirations, ${ }^{6}$ to those responding to particular situations ${ }^{7}$ and a myriad of other subjects too many to mention.

My second thought, which emerges from this overview of the nature and scope of our legislation, is equally trite and elementary, but is also worth recording. There is today little pure common law left and that which is left is heavily affected or influenced by statute law: contract law by the contract statutes $;{ }^{8}$ tort law by the accident compensation legislation, ${ }^{9}$ the Defamation Act 1992, and others; ${ }^{10}$ and equity by the Trustee Act 1956 and many others. ${ }^{11}$ Even the common law of contempt of court, which is preserved by s 9 of the Crimes Act 1961 and which I will come back to,

1 The Constitution Act 1986; the Electoral Act 1993; the Local Government Act 2002; the Judicature Act 1908; the Treaty of Waitangi Act 1975; the Public Finance Act 1989; the State Sector Act 1988; the Crown Entities Act 2004; and the Legislation Act 2012.

2 The New Zealand Bill of Rights Act 1990; the Human Rights Act 1993; the Privacy Act 1993; and the Official Information Act 1982.

3 The Income Tax Act 2007.

4 The Defence Act 1990; the Health Act 1956; the Social Security Act 1964; the Crimes Act 1961; the Sentencing Act 2002; the Search and Surveillance Act 2012; the Evidence Act 2006; the Criminal Procedure Act 2011; and the Juries Act 1981.

5 The Lawyers and Conveyancers Act 2006; the Health Practitioners Competence Assurance Act 2003; the Education Act 1989; the Real Estate Agents Act 2008; and the Plumbers, Gasfitters, and Drainlayers Act 2006.

6 The Property Law Act 2007; the Land Transfer Act 1952; the Companies Act 1993; the Commerce Act 1986; the Financial Markets Conduct Act 2013; the Sale of Goods Act 1908; the Contractual Remedies Act 1979; the Contractual Mistakes Act 1977; the Illegal Contracts Act 1970; the Trustee Act 1956; and the Resource Management Act 1991.

7 The Property (Relationships) Act 1976; the Canterbury Earthquake Recovery Act 2011; and the StateOwned Enterprises Act 1986.

8 The Contractual Remedies Act 1979; the Contractual Mistakes Act 1977; the Illegal Contracts Act 1970; and the Frustrated Contracts Act 1944. See also the Contract and Commercial Law Bill 2016 (134-1) which when enacted will consolidate and update many contract and commercial Acts.

9 Accident compensation legislation has undergone many iterations since the original Accident Compensation Act 1972 envisaged by the Woodhouse Report. The current Act is the Accident Compensation Act 2001, amended by the Accident Compensation Amendment Act 2010.

10 The Trespass Act 1980; the Privacy Act 1993; and the Crown Proceedings Act 1950. Crown liability in tort was recently subject to a Law Commission report The Crown in Court: A Review of the Crown Proceedings Act and National Security Information in Proceedings (NZLC R135, 2015).

11 The Trustee Act 1956; the Wills Act 2007; the Perpetuities Act 1964; the Administration Act 1969; the Charitable Trusts Act 1957; the Family Protection Act 1955; and the Law Reform (Testamentary Promises) Act 1949. 
is modified by multiple statutes. ${ }^{12}$ In Vector Ltd v Transpower New Zealand Ltd, Richardson P made this point in relation to the common law doctrine of prime necessity which he said needed to be viewed in "the complex environment of a modern economy and extensive legislative landscape". ${ }^{13}$

My third thought is that, as a result, most of the work of courts today involves the interpretation and application of statutes to a greater or lesser degree. ${ }^{14}$ Forty one per cent of Court of Appeal and Supreme Court judgments in 2006 were "true" statutory interpretation cases - where the meaning of a statutory provision was at the heart of the issue (as opposed to fact based disputes focusing on the application of a statute). ${ }^{15}$ In the first 10 years of the Supreme Court, 60 per cent of all appeals involved the interpretation of a statutory provision. ${ }^{16}$ And almost all criminal cases would have involved, in one way or another, the application of statutory provisions. ${ }^{17}$

My final thought, which is a direct consequence of the first three, is to recognise the importance and responsibilities of parliamentary counsel, current and past, not only for drafting most of this legislation, ${ }^{18}$ but also for implementing the policies of governments by translating the language of politics and policy into law. I am not sure the challenges inherent in this exercise are always appreciated by those responsible for the policies or those responsible for interpreting and applying the finished product. I expect the risk of criticism - something important was lost in translation - is inevitably a factor in the work of parliamentary counsel. The task of translation from policy to law

12 The New Zealand Bill of Rights Act 1990; the Judicature Act 1908; the District Courts Act 1947; the Criminal Procedure Act 2011; and the Habeas Corpus Act 2001, s 19.

13 Vector Ltd v Transpower New Zealand Ltd [1999] 3 NZLR 646 (CA) at [51]; and Douglas White "Facilitating and Regulating Commerce" in David Carter and Matthew Palmer (eds) Roles and Perspectives in the Law: Essays in Honour of Sir Ivor Richardson (Victoria University Press, Wellington, 2002) 821 at 836.

14 The Rt Hon Dame Sian Elias noted that New Zealand had placed heavy reliance on statute law since settlement: Sian Elias, Chief Justice of New Zealand "Transition, Stability and the New Zealand Legal System" (FW Guest Memorial Lecture, Dunedin, 23 July 2003) at 10. In New Zealand Maori Council v Attorney-General [1987] 1 NZLR 641 (CA) at 651 Cooke P said that the issue of statutory interpretation in that case was "perhaps as important for the future of our country as any that has come before a New Zealand Court".

15 Cathy Nijman "Ascertaining the Meaning of Legislation - A Question of Context" (2007) 38 VUWLR 629 at 656 and 663 per Appendix A.

16 Mary-Rose Russell and Matthew Barber "Empirical Analysis of Supreme Court Decisions" in Mary-Rose Russell and Matthew Barber (eds) The Supreme Court of New Zealand 2004-2013 (Thomson Reuters, New Zealand, Wellington, 2015) 1 at 19.

17 The Crimes Act 1961; the Summary Offences Act 1981; the Search and Surveillance Act 2012; the Criminal Procedure Act 2011; the Evidence Act 2006; and the Sentencing Act 2002.

18 Some tax law is drafted by the Inland Revenue Department's (IRD's) Tax Law Drafting Unit, working with and instructed by IRD's Policy Advice Division. 
involves recognising the critical differences between the language of politics, policy and the law. ${ }^{19}$ The principal task of parliamentary counsel therefore is to ensure, to the best of their abilities and subject no doubt to the vagaries of select committees and supplementary order papers, that the finished product - the statute they draft - reflects and implements the policy in such a way that the statute will be interpreted and applied as intended. In other words, it works in accordance with its purpose as Parliament intends.

\section{NORTHERN MILK}

These four preliminary thoughts segue into my thesis which relates to the responsibilities of all those required to interpret and apply legislation (citizens, public servants, lawyers, courts and tribunals) and which is based on the decision of the Court of Appeal in Northland Milk Vendors Association Inc $v$ Northern Milk Ltd (Northern Milk) ${ }^{20}$ and the statement by Cooke P delivering the judgment of the Court (comprising Cooke P, McMullin and Somers JJ): "the Courts must try to make the Act work while taking care not themselves to usurp the policy-making function, which rightly belongs to Parliament". ${ }^{21}$

These simple, clear words represent in my view the best articulation of the principal function of a court when approaching its task of statutory interpretation. The overarching objective is to "make the Act work". All of the well-known principles of statutory interpretation (enacted in the Interpretation Act 1999, applied by the Supreme Court in Commerce Commission v Fonterra Cooperative Group Ltd ${ }^{22}$ and Fonterra Co-operative Group Ltd v The Grate Kiwi Cheese Co Ltd, ${ }^{23}$ and described in Burrows and Carter Statute Law in New Zealand) ${ }^{24}$ are designed to achieve that practical objective.

To ascertain meaning, a court should look principally at the text of the relevant statutory provision in light of its purpose taking into account the immediate and general legislative context, and recognising the social, commercial or other objective of the enactment. But in doing so, the court is endeavouring to "make the Act work" and, in my view, that requires, pre-eminently, a common sense and practical approach. Courts are entitled to assume Parliament intends its

19 Matthew SR Palmer "Open the Doors and Where are the People? Constitutional Dialogue in the Shadow of the People" in Claire Charters and Dean Knight (eds) We, the People(s): Participation in Governance (Victoria University Press, Wellington, 2011) 50 at 60.

20 Northland Milk Vendors Association Inc v Northern Milk Ltd [1988] 1 NZLR 537 (CA).

21 At $537-538$

22 Commerce Commission v Fonterra Co-operative Group Ltd [2007] NZSC 36, [2007] 3 NZLR 767 at [22].

23 Fonterra Co-operative Group Ltd v The Grate Kiwi Cheese Co Ltd [2012] NZSC 15, [2012] 2 NZLR 184 at [14]-[16].

24 Ross Carter (ed) Burrows and Carter Statute Law in New Zealand (5th ed, Lexis Nexis, Wellington, 2015) at 220 . 
legislation to work in that way. An interpretation which does not have that outcome and which might be described as frustrating Parliament's purpose is unlikely to be correct.

As Cooke P was at pains to emphasise, however, this does not mean the court should "usurp the policy-making function, which rightly belongs to Parliament". The next sentence in the Northern Milk judgment puts this qualification beyond doubt: "The Courts can in a sense fill gaps in an Act but only in order to make the Act work as Parliament must have intended." ${ }^{25}$ Here again we have reference to the overarching objective of making the Act work because that is what Parliament must have intended. In support of this proposition, Cooke P cited the decisions of the Court of Appeal in Goodman Fielder Ltd v Commerce Commission ${ }^{26}$ and New Zealand Labourers' Union v Fletcher Challenge ${ }^{27}$ both of which he wrote for the Court.

It is here too that the role of parliamentary counsel is critical: translating the policy into workable legislation that implements Parliament's purpose.

Northern Milk was concerned with a gap in the legislation, the Milk Act 1988, enacted by Parliament to restructure the town milk industry and partly to deregulate it, with a view to possible ultimate complete deregulation. The problem was that the legislation did not deal specifically with what was to happen about home deliveries in the short interval before the new administrative control system introduced by the new Act came into effect. After a close examination of the scheme of the new Act, the Court of Appeal concluded: ${ }^{28}$

Parliament must have intended that after the 1988 Act came into force the frequency of home deliveries

would continue as specified in the approvals applying immediately before then as between the Milk

Board and the vendors.

The Court made the Act work by filling the gap in the legislation and upheld an injunction granted in the High Court to preserve the status quo.

Nowadays Northern Milk is referred to principally as authority for filling gaps in legislation rather than about the overarching objective of making legislation work. ${ }^{29}$ Indeed the decision is

25 Northern Milk, above n 20, at 538.

26 Goodman Fielder Ltd v Commerce Commission [1987] 2 NZLR 10 (CA).

27 New Zealand Labourers' Union v Fletcher Challenge [1988] 1 NZLR 520 (CA)

28 Northern Milk, above n 20, at 542.

29 Carter, above $\mathrm{n} 24$, at 231. The author further describes the case as "bridg[ing] a hiatus" between the statute and the facts at hand, but always tempered by the caveat that judges should not bridge "if the legislation can be interpreted sensibly as it stands". See also Ross Carter "Statutory Interpretation and the Rectification of Drafting Errors" [2012] NZ L Rev 207 at 217. 
sometimes criticised as having gone too far by encroaching on Parliament's legislative function. ${ }^{30}$ Glazebrook J, in a 2003 Legal Research Foundation conference paper, writes in favour of judges filling gaps, but also describes the decision as "controversial" and one often relied on by counsel effectively as an authority of last resort. ${ }^{31}$

To the extent Northern Milk has been consigned to footnotes about gaps in legislation, it has perhaps soured, particularly because there are now fortunately relatively few gaps to be filled. This no doubt reflects both the absence of 1980s parliamentary legislative pressures and the presence of parliamentary counsel determined to ensure by their work no such gaps appear, even inadvertently, in modern legislation. It may also reflect the willingness of courts today to view any gap in the text of any provision as simply not reflecting Parliament's purpose in the wider context of the particular legislation. At the same time, however, a court will still, if necessary, follow Northern Milk and read words into a statute to fill an obvious gap. ${ }^{32}$

\section{A PERSONAL PERSPECTIVE}

In my view Northern Milk remains, or at least should remain, fresh today as authority for the proposition that all legislation should be interpreted to make it work as Parliament intended and this requires a common sense and practical approach. When implementing Parliament's purpose and recognising "the social, commercial or other objective of the enactment"33 nothing less is appropriate.

In order to provide my perspective on legislation, I follow in the footsteps of Cooke $\mathrm{P}$ in Northern Milk by citing two recent decisions of the Court of Appeal where the Court effectively treated Northern Milk as fresh today. The Court did so by focusing on making the particular legislation involved in the case work rather than by seeing any need to fill a gap.

The first, Teddy $v$ New Zealand Police, ${ }^{34}$ was a case about a prosecution against a fisherman for operating his boat in a manner that caused unnecessary risk to a marine survey vessel which was looking for oil in the Raukumara Basin outside the 12 nautical mile limit of New Zealand's territorial sea contrary to s 65(1)(a) of the Maritime Transport Act 1994. ${ }^{35}$ The particular issue was

30 DF Dugdale "Framing Statutes in an Age of Judicial Supremacism" (2000) 9 Otago LR 603 at 608; and Alan Galbraith QC "Sources of Problems of Interpretation: A Commentary" in Rick Bigwood (ed) The Statute Making and Meaning (LexisNexis, Wellington, 2004) 179 at 183-184.

31 Susan Glazebrook "Filling the Gaps" in Rick Bigwood (ed) The Statute Making and Meaning (LexisNexis, Wellington, 2004) 153 at 167 and 176.

32 Glynbrook 2001 Ltd v Official Assignee [2012] NZCA 289 at [45]

33 Commerce Commission v Fonterra Co-operative Group Ltd, above n 22, at [22].

34 Teddy $v$ Police [2014] NZCA 422, (2014) 27 CRNZ 1.

35 As it was before being amended in 2013. 
whether the District Court had jurisdiction in respect of an offence under s 65(1)(a) outside the 12 mile limit.

The District Court Judge decided the Court did not have jurisdiction, but his decision was overturned by the High Court, and the Court of Appeal upheld the High Court decision. Leave to appeal to the Supreme Court was declined, essentially because the 2013 amendment to the Act meant no point of general or public importance arose. ${ }^{36}$

In summarising the relevant principles of statutory interpretation the Court of Appeal in Teddy said: "Legislation should be interpreted in a realistic and practical manner in order to ensure it works as intended." ${ }^{37}$ Northern Milk was cited as authority for this proposition. This approach assisted the Court in concluding that s 65(1)(a) was intended to have extraterritorial effect beyond the 12 mile limit. The Court said: ${ }^{38}$

From a practical point of view, it would be strange if offences of this nature should depend for their existence on whether the alleged breach occurred at the outer reach of the 12 nautical mile limit or just beyond it. The public safety purpose of s 65 does not support a territorial limitation of this nature, especially in the context of New Zealand's geography with coastal shipping between the country's various islands inevitably passing through areas outside the territorial sea.

I venture to suggest this was a common sense approach to making the legislation work in accordance with Parliament's purpose.

The second recent Court of Appeal decision is Chief Executive of the Ministry of Social Development $v$ Greenfield. ${ }^{39}$ This case involved a New Zealand missionary who had lived in Singapore for some 20 years and whose application for New Zealand superannuation had been declined by the Chief Executive under s 8(a) of the New Zealand Superannuation and Retirement Act 2001 on the ground Mrs Greenfield was not "ordinarily resident" in New Zealand. The Chief Executive's decision was upheld by a Benefits Review Committee and by the Social Security Appeal Authority. Mrs Greenfield's appeal to the High Court was successful, but the High Court decision was overturned by the Court of Appeal. The Supreme Court granted leave to appeal, but dismissed the appeal. ${ }^{40}$

36 Teddy v New Zealand Police [2015] NZSC 6 at [11]-[12].

37 Teddy v Police, above n 34, at [30]. Reference was also made at [33] to the relevance of New Zealand's international treaty obligations.

38 At [44].

39 Chief Executive of the Ministry of Social Development v Greenfield [2014] NZCA 611, [2015] 3 NZLR 117.

40 Greenfield v Chief Executive of the Ministry of Social Development [2015] NZSC 139, [2016] 1 NZLR 261. 
Without expressly referring to Northern Milk, the Court of Appeal adopted a practical approach to the interpretation of the expression "ordinarily resident" in the legislation. ${ }^{41}$ The Court took into account the following factors: ${ }^{42}$

When a practical approach is adopted taking into account the following factors we have little difficulty in concluding that Parliament intended the degree of connection to be close and easily able to be determined:

(a) As at 2013 New Zealand superannuation cost the New Zealand taxpayer annually some $\$ 8.8$ billion in after tax costs ( $\$ 10.2$ billion before tax) or between four and five per cent of GDP.

(b) As at June 2013 some 653,247 people were in receipt of New Zealand superannuation (and another 8,445 receive veteran's pensions) with the number estimated to increase to over 1,100,000 by 2031 .

(c) In each of the last two years approximately 27,000 people have applied for New Zealand superannuation.

(d) Administration of New Zealand superannuation involves significant costs to the Ministry of Social Development.

The Court of Appeal then said: ${ }^{43}$

Adopting a practical approach here, we are satisfied that in order to implement the purpose of the Act by requiring a close and clear connection between an applicant and New Zealand, the expression "ordinarily resident" should be interpreted to cover the following further elements:

(a) Physical presence here other than casually or as a traveller;

(b) Voluntary presence;

(c) Some intention to remain in the country for a settled purpose;

(d) Continuing residence despite any temporary absences; and

(e) Residence in New Zealand rather than anywhere else. The Act is not one which permits residence in two countries simultaneously.

While the Supreme Court dismissed the appeal, it did say this: ${ }^{44}$

In respectful disagreement with the Court of Appeal, we do not see the cost of New Zealand superannuation as being of moment and thus do not regard the considerations referred to by the Court of

41 Chief Executive of the Ministry of Social Development v Greenfield, above n 39, at [31]-[32].

42 At [31].

43 At [32].

44 Greenfield v Chief Executive of the Ministry of Social Development, above n 40, at [33]. 
Appeal in [31] of its judgment as material to the application of the concepts of residence and ordinary residence.

I accept of course that the Supreme Court was fully entitled to take this approach and that, in hindsight, the Court of Appeal might perhaps have spelt out more clearly the connection between the factors at [31] of its judgment with the interpretation of the phrase "ordinarily resident". The connection which would have been spelt out was that the costs and numbers of applications involved in New Zealand superannuation meant that Parliament would have intended the meaning of the phrase to be determined "easily" and in a relatively straightforward manner; in other words, in a manner that made the Act work in a practical and common sense way, an approach which has in fact been followed by the Court of Appeal relying on Northern Milk in several other decisions in recent years. ${ }^{45}$

\section{A LESSON}

In this context the lesson here for me in my role at the Law Commission is to ensure that its reports and any recommendations for statutory reform comply with the requirements of s 5 of the Law Commission Act 1985, which in prescribing its functions provides that, amongst other matters, it must "advise the Minister of Justice and the responsible Minister on ways in which the law of New Zealand can be made as understandable and accessible as is practicable"; 46 and "have regard to the desirability of simplifying the expression and content of the law, as far as that is practicable". 47

A similar approach was adopted by Parliament 27 years later in the Legislation Act 2012 which continues the PCO. Under s 3(e) one of the purposes of the Act is:

... to make New Zealand statute law more accessible, readable, and easier to understand by facilitating the progressive and systemic revision of the New Zealand statute book so that-

(i) statute law is rationalised and arranged more logically:

(ii) inconsistencies and overlaps are removed:

(iii) obsolete and redundant provisions are repealed:

45 Canterbury Regional Council v Independent Fisheries Ltd [2012] NZCA 601, [2013] 2 NZLR 57 at [12] (leave to appeal refused: Independent Fisheries Ltd v Minister for Canterbury Earthquake Recovery [2013] NZSC 35); Postal Workers Union of Aotearoa Inc v New Zealand Post Ltd [2012] NZCA 481, [2013] 1 NZLR 66 at [32] (leave to appeal refused: New Zealand Post Ltd v Postal Workers Union of Aotearoa Inc [2013] NZSC 14); SMW Consortium (Golden Bay) Ltd v Chief Executive of the Ministry of Fisheries [2013] NZCA 95 at [23]; New Zealand Law Society v B [2013] NZCA 156, [2013] NZAR 970 at [24]; Strategic Finance Ltd (in rec and in liq) v Bridgman [2013] NZCA 357, [2013] 3 NZLR 650 at [46]; and Chorus Ltd v Commerce Commission [2014] NZCA 440 at [43].

46 Law Commission Act 1985, s 5(1)(d).

47 Section 5(2)(b). 
(iv) expression, style, and format are modernised and made consistent:

And under s $3(\mathrm{~g})$ another purpose is to facilitate the drafting and publishing of "high quality legislation" which would meet similar requirements of accessibility, readability and understandability. ${ }^{48}$

There are several good reasons why these statutory provisions governing the Law Commission and the PCO should be read together in a practical and common sense manner in order to make them work as Parliament clearly intended.

First, they are part of the same "legislative landscape". Both sets of provisions impose common objectives in relation to the same subject matter, namely the quality of New Zealand's legislation and the requirements that it be accessible, understandable and simplified.

Secondly, the requirements relate to two independent institutions which have complementary roles in New Zealand's constitutional democracy: the Law Commission with responsibility for making proposals for the reform of the law of New Zealand and the PCO with responsibility for drafting the legislation implementing law reform proposals accepted by the Government. ${ }^{49}$

Thirdly, in recognition of these common objectives and complementary roles, the Executive Government has taken steps to indicate it expects close co-operation between the Law Commission and the PCO. The Cabinet Manual encourages Ministers to consult the PCO before proposing a legislation project for the Law Commission's work programme. ${ }^{50}$ The Cabinet Manual also requires the Commission and relevant government agencies, such as the PCO, to collaborate closely during the course of a Commission project. ${ }^{51}$ And the Cabinet Office Circular relating to the process for setting the Law Commission's work programme addresses how the PCO should work with the Commission. ${ }^{52}$ This may include the provision of legislative drafting assistance if the nature of the Commission's report is such that it would be appropriate to append a draft Bill to it.

Fourthly, all New Zealand legislation is now available online and therefore readily accessible to anyone who has access to the internet. The website www.legislation.govt.nz was set up by the PCO in 2002 and now provides, without charge, official and up-to-date versions of all New Zealand

48 Ross Carter "High-quality Legislation - (How) Can Legislative Counsel Facilitate It?" The Loophole (November 2011) at 41

49 Legislation Act 2012, ss 3(g) and 66.

50 See Cabinet Office Cabinet Manual 2008 at [7.17].

51 At [7.18].

52 Cabinet Office Circular "Law Commission: Processes for Setting the Work Programme and Government Response to Reports" (24 April 2009) CO (09) 1 at [9]-[10] and [14]. 
legislation. It is no longer necessary to purchase hard copies of statutes, let alone subscribe to bound sets requiring annual annotation.

Any doubts about the ability of New Zealanders to take advantage of this new ready accessibility to their legislation are answered by the statistics. ${ }^{53}$ The website currently receives on average some 8,219 unique visits a day, of over five minutes each, an increase of 150 per cent over the last five years. ${ }^{54}$ Interestingly, the most popular statutes in descending order are: the Resource Management Act 1991; the Companies Act 1993; the Health and Safety at Work Act 2015; the Employment Relations Act 2000; the Income Tax Act 2007; and the Crimes Act 1961. New Zealand legislation is also available online through the websites of commercial publishers such as LexisNexis and Westlaw New Zealand which, for a charge, provide the legislation often with a commentary referring to relevant court decisions.

While a significant proportion of the visits to the legislation websites is likely to be made by lawyers, an equally significant proportion is likely to be made by other New Zealanders. New Zealand's legislation is therefore not only easily accessible but is in fact being accessed directly by members of the public. In the context of the digital age the statutory obligation on the PCO to make New Zealand statute law more accessible by making it more available may be considered to be largely met by the establishment and ongoing maintenance of its website.

To the extent that the parallel obligation imposed on the Law Commission relates to statute law, it may also be considered to be met by the New Zealand Legislation website made available by the PCO. The fact that the Commission's obligation was imposed in 1985 before the advent of the internet in New Zealand simply recognises the well-established principle of statutory interpretation that legislation should be read as continuing to speak, ${ }^{55}$ here in the light of unanticipated technological developments.

It is unlikely that all the consequences of the new general public accessibility to all legislation have yet been fully appreciated. For present purposes, however, it means that the further obligations imposed on both the Law Commission and the PCO respectively to propose and draft "understandable" and "simplified" legislation are starkly highlighted. Unduly complex statutory provisions, which are difficult to understand, will not survive without criticism the new bright light of public internet scrutiny.

While in this context the Law Commission Act 1985 qualifies the Commission's obligations by reference to a test of practicability, it is interesting to note the absence of an equivalent qualification

53 Susan Glazebrook "Do they say what they mean and mean what they say? Some issues in statutory interpretation in the 21st century" (2015) 14 Otago LR 61 at 62-63.

54 Parliamentary Counsel Office Annual Report for the year ended 30 June 2016 (forthcoming).

55 Interpretation Act 1999, s 6; and Carter, above n 24, at 410. 
in the drafting of the obligations imposed on the PCO. This distinction is unlikely to be of any particular significance if both sets of obligations are interpreted so as to make them work together in a practical and common sense manner. Clearly, the need for clear and easily understandable statutory language remains paramount and ought to be achievable. ${ }^{56}$

It is also noteworthy that the Commission's ongoing obligation to make all the law of New Zealand as accessible as practicable is not limited to statute law. It extends to the common law and court decisions interpreting statutory provisions. Questions for further consideration in the digital age may include whether there should be hyperlinks from the official online legislation website to summaries of relevant court decisions, legal writing and even the names of lawyers who practise in the particular field.

In this context it is interesting to recall that the 1931 Public Acts of New Zealand included summaries of key cases, ${ }^{57}$ a practice not followed in subsequent reprints. The current practice of courts publishing their decisions on the internet might encourage the return of this approach by the addition of appropriate hyperlinks.

\section{AN EXAMPLE}

The Law Commission's reference on the law of contempt of court ${ }^{58}$ has been reactivated after it was put on hold last year to enable the Commission to give priority to its three reports for the Government's family violence project ${ }^{59}$ and the report on the use of national security information. ${ }^{60}$ In accordance with the Cabinet Office Circular I have mentioned, ${ }^{61}$ the PCO has already been involved in drafting a bill for inclusion in the Commission's contempt of court report.

The contempt of court reference raises a range of critical issues, including issues affected by the internet and social media. Today everyone, including the media, citizen journalists, bloggers, and jurors, has the ability to obtain information about anything and anyone, including parties and witnesses and their views and actions, as well as judges and lawyers and their families, and to disseminate that information together with opinions or comments, both informed and uninformed,

56 Glazebrook, above n 53, at 63-67.

57 Michael Myers, W Downie Stewart and James Christie (eds) The Public Acts of New Zealand (reprint, Butterworths, Wellington, 1931).

58 Law Commission "Contempt of Court" <www.lawcom.govt.nz>.

59 Law Commission The Justice Response to Victims of Sexual Violence: Criminal Trials and Alternative Processes (NZLC R136, 2015); Law Commission Strangulation: The Case for a New Offence (NZLC R138, 2016); and Law Commission Understanding Family Violence: Reforming the Criminal Law Relating to Homicide (NZLC R139, 2016).

60 The Crown in Court, above n 10.

61 Cabinet Office Circular, above n 52. 
instantaneously and permanently and, directly or indirectly, to the world. Issues relating to googling jurors, online campaigns in specific cases and websites devoted to attacks on judges have already arisen.

In New Zealand we have had a case involving a blogger who breached a series of District Court name suppression orders by "publishing" the names on his website, including by way of a hypertext link to a newspaper report of the particular proceedings. His argument that this did not constitute publication "in any report or account relating to any proceedings" was rejected in the District Court and on appeal to the High Court. ${ }^{62}$ Both Courts accepted that the then relevant provisions of the Criminal Justice Act 1985 should be interpreted as continuing to speak in the digital age. ${ }^{63}$ Leave to appeal to the Court of Appeal was granted by the High Court, but not pursued. ${ }^{64}$ The challenge now is to draft legislation able to be applied in a world of vast and rapid technological change. ${ }^{65}$

The Commission's specific challenge in the reactivated contempt of court reference is to make recommendations, and to draft legislation, that work in a practical and common sense way to support the administration of justice (and hence uphold the rule of law) by:

(a) maintaining the fair trial rights of defendants through the ability of the courts to make and enforce appropriate suppression, non-publication and take down orders, to give and enforce appropriate jury directions, and to make and enforce other appropriate orders during a trial to ensure it proceeds in an orderly and expeditious fashion; and

(b) providing courts with appropriate legislative authority for sanctions for the enforcement of their judgments and orders rather than leaving that to the common law; while also

(c) allowing criticism, including forceful criticism, of judges and their decisions, but permitting courts to draw the line when the criticism is outrageous and undermines public confidence in the judiciary itself.

All of this must be done while recognising the right to freedom of expression affirmed by s 14 of the New Zealand Bill of Rights Act 1990 and the requirement in s 5 of that Act that the statutory rights and freedoms may be subject only to such reasonable limits as can be demonstrably justified

62 Police v Slater [2011] DCR 6; and Slater v New Zealand Police HC Auckland CRI-2010-404-379, 10 May 2011 at [67]-[71].

63 Police v Slater, above n 62, at [134]; Slater v New Zealand Police, above n 62, at [9]; and David Harvey Internet.law.nz: Selected Issues (4th ed, LexisNexis, Wellington, 2016) at [4.109].

64 Slater v New Zealand Police HC Auckland CRI-2010-404-379, 8 July 2011; and Slater v R [2011] NZCA 568 .

65 Drafters are well aware of the desirability of "technological neutrality" in legislation, to make the legislation durable: see for example Geoff Lawn "Achieving technological neutrality in drafting legislation" The Loophole (January 2014) at 29. 
in a free and democratic society. ${ }^{66}$ The challenges involved for the law of freedom of expression in the digital age are well described in Free Speech Ten Principles for a Connected World. ${ }^{67}$

\section{CONCLUSION}

My first six months at the Law Commission have included focussing on its relationship with the PCO and its contempt of court reference. These experiences have highlighted the complementary statutory obligations on both the Commission and the PCO to propose and draft legislation which is accessible, understandable and simplified. When the challenges involved in doing so in the digital age are recognised, there is little doubt in my view that the overarching objective of statutory interpretation articulated by Cooke P in Northern Milk remains apposite.

$66 R v$ Hansen [2007] NZSC 7, [2007] 3 NZLR 1 at [63] per Blanchard J, at [101]-[102] per Tipping J, at [180] per McGrath J, and at [265]-[266] per Anderson J (for the majority on the s 5 issue), and at [15]-[24] per Elias CJ (dissenting on the s 5 issue).

67 Timothy Garton Ash Free Speech Ten Principles for a Connected World (Yale University Press, New Haven, 2016). 